\title{
Skrining Fitokimia dan Potensi Antilitiasis dari Ekstrak Etanol Daun Nusa Indah Putih (Mussaenda pubescens)
}

\section{Emma J. Pongoh*, Rymond J. Rumampuk, Dian H.O Howan, Veyta Tamunu}

Kimia, Universitas Negeri Manado, Tondano, 95619, Indonesia

\begin{tabular}{l} 
I N F O A R T I K E L \\
\hline Diterima 01 Oktober 2019 \\
Disetujui 25 Oktober 2019 \\
\\
\hline Key word: \\
Phytochemical screening, \\
antilithiasis, \\
nusa indah putih leaf \\
\hline Kata kunci: \\
skrining fitokimia, \\
antilitiasis, \\
daun nusa indah putih
\end{tabular}

${ }^{*} e-$ mail

julin.pongoh@yahoo.co.id:

*Telp:

$+6282185880314$

\begin{abstract}
The phytochemical screening and antilitiasis assay have been done on the ethanolic extract of nusa indah putih leaf (Mussaenda pubescens). The screening phyticemical results showed that the leaves of nusa indah putih (M. pubescens) positively contain alkaloids and flavonoids. Antilitiasis assay results showed effectiveness in improving urolithiasis rats at doses of $300 \mathrm{mg} / \mathrm{kg}$ BW better in improving kidney compared to dose $150 \mathrm{mg} / \mathrm{kg} B W$ with a concentration of $1.8 \mathrm{ml} / \mathrm{rat}$.
\end{abstract}

\section{A BSTRAK}

Skrining fitokimia dan uji antilitiasis telah dilakukan pada ekstrak etanol daun nusa indah putih (Mussaenda pubescens). Hasil skrinig fitokimia menunjukkan bahwa daun nusa indah putih (M. pubescens) positif mengandung alkaloid dan flavonoid. Hasil uji antilitiasis menunjukkan efektivitas dalam memperbaiki tikus urolitiasis dengan dosis $300 \mathrm{mg} / \mathrm{kg}$ BB lebih baik dalam memperbaiki ginjal dibandingkan dengan dosis $150 \mathrm{mg} / \mathrm{kg}$ BB dengan konsentrasi 1,8 ml/tikus.

\section{Pendahuluan}

Tumbuhan obat merupakan tumbuhan yang memiliki khasiat obat dalam mengobati maupun mencegah suatu penyakit. Sebagian masyarakat memilih menggunakan obat tradisional dalam menyembuhkan atau mencegah suatu penyakit yang disebabkan karena tingginya harga obat di pabrik yang tidak diimbangi dengan daya beli masyarakat. Indonesia merupakan salah satu negara dengan kekayaan hayati terbesar yang memiliki lebih dari 30.000 spesies tanaman tingkat tinggi. Hingga saat ini tercatat 7.000 spesies tanaman telah diketahui khasiatnya namun kurang dari 300 tanaman yang digunakan sebagai bahan baku industri farmasi secara reguler. WHO pada tahun 2008 mencatat bahwa 68\% penduduk dunia masih menggantungkan sistem pengobatan tradisional yang mayoritas melibatkan tumbuhan untuk menyembuhkan penyakit dan lebih dari $80 \%$ penduduk dunia menggunakan obat herbal untuk mendukung kesehatan mereka [1].

Salah satu penyakit yang banyak diobati dengan tanaman obat adalah penyakit batu ginjal. Di dunia, diperkirakan terdapat $12 \%$ kejadian batu ginjal di mana $70-81 \%$ adalah lakilaki dan hanya $47-60 \%$ terdapat pada perempuan, khususnya pada usia 40-50 tahun $[2,3]$. Batu ginjal merupakan material-material kristal yang keras yang berbentuk dalam ginjal atau traktus urinaria, terbentuk akibat kelebihan garam di aliran darah yang kemudian mengkristal di ginjal. Bentuk dan ukurannya bermacam-macam, yang dapat menimbulkan rasa sakit yang hebat serta pendarahan ringan. Batu ginjal tidak dapat larut hanya dengan mengatur pola diet. Penggunaan obat-obatan seperti diuretik hingga operasi pengangkatan batu tentu memiliki resiko tinggi dan biaya yang mahal [2]. Salah satu obat herbal yang juga selama ini digunakan secara empiris untuk mengatasi batu ginjal adalah daun dari tumbuhan nusa indah 
putih (Mussaenda pubescens). Nusa indah putih (Mussaenda pubescens) termasuk dalam genus Mussaenda yang secara farmakologi memiliki produk alamiah aktif khususnya iridoid, triterpen dan flavonoid. Keuntungan spesies dari genus ini mudah bertumbuh, bebas penyakit dan peptisida. Analisis fitokimia dari bagian tanaman nusa indah putih (Mussaenda pubescens) mengandung triterpenoid saponin [4].

Masyarakat di Sulawesi Utara pemanfaatan daun nusa indah putih untuk pengobatan batu ginjal selama ini belum banyak dilakukan. Untuk itu perlu dilakukan penelitian terhadap beberapa senyawa yaitu alkaloid, flavonoid dan saponin melalui uji skrining fitokimia dan efektivitas daun nusa indah putih (Mussaenda pubescens) sebagai antilitiasis pada hewan uji tikus putih (Rattus norvegicus) dengan melihat perubahan histopatologi ginjal.

\section{Bahan dan Metode}

\section{Skrining Fitokimia \\ Uji Alkaloid}

Sebanyak $2 \mathrm{~g}$ sampel ditambahkan $5 \mathrm{~mL}$ kloroform dikocok kemudian dipisahkan kedalam tabung A dan B sebanyak 10 tetes, masing-masing tabung ditambahkan dengan 10 tetes $\mathrm{H}_{2} \mathrm{SO}_{4} 2 \mathrm{~N}$ dikocok kuat, kemudian tabung A ditambahkan reagen Wagner dan tabung B ditambahkan reagen Mayer masing-masing sebanyak 2 tetes. Adanya alkaloid ditandai dengan terbentuknya endapan kecokelatan oleh pareaksi Wagner dan terbentuknya endapan krem pada pereaksi Mayer [5].

\section{Uji Flavonoid}

Sebanyak $4 \mathrm{~g}$ sampel dibagi menjadi 2 tabung dengan masing-masing tabung sebanyak $2 \mathrm{~g}$ sampel, kemudian tiap tabung diestraksi dengan metanol sebanyak $3 \mathrm{~mL}$, disaring. Tabung A ditambahkan $\mathrm{H}_{2} \mathrm{SO}_{4}$ sebanyak 2 tetes dan tabung B ditambahkan $\mathrm{NaOH} 10 \%$ sebanyak 2 tetes kemudian dikocok kuat. Terbentuknya warna kuning, merah atau cokelat pada tabung A menunjukkan adanya flavonoid. Kemudian pada tabung B bila terjadi perubahan warna kuning, merah, cokelat atau hijau menunjukkan adanya flavonoid.

\section{Uji Saponin}

Sebanyak $2 \mathrm{~g}$ sampel diekstraksi dengan air panas sebanyak $5 \mathrm{~mL}$, disaring dan dikocok kuat kemudian diamkan selama 2 menit. Tambahkan $\mathrm{HCl} 2 \mathrm{~N}$ sebanyak 2 tetes, kocok kuat dan diamkan selama 10 menit. Adanya saponin ditunjukkan dengan terdapat buih/busa dengan intensitas yang banyak dan konsisten selama 10 menit.

\section{Tahap Preparasi Sampel}

Tahap preparasi sampel, daun nusa indah putih sebanyak $6 \mathrm{~kg}$ dibersihkan, dikeringkan dalam suhu ruang dengan dibantu alat pengering (kipas angin), kadar air diukur dan didapat 5\%. Daun kering sebanyak $1,5 \mathrm{~kg}$ dihaluskan dengan cara diblender lalu diayak menggunakan ayakan 40 mesh, sehingga diperoleh serbuk kering sebanyak $1,4 \mathrm{~kg}$.

\section{Pembuatan Ekstrak Etanol}

Tahap ekstraksi dilakukan dengan cara maserasi yaitu serbuk kering daun nusa indah putih sebanyak $1,4 \mathrm{~kg}$ dimaserasi dengan etanol $70 \%$, sehingga memperoleh filtrat, kemudian disaring menggunakan kertas saring dan diperoleh filtrat sebanyak 11,244 L, lalu filtrat dievaporasi dan didapat ekstrak kental etanol sebanyak $217,72 \mathrm{~g}$.

\section{Uji Efektivitas Antilitiasis}

Setelah adaptasi, tikus perlakuan untuk kontrol (P0) hanya diberi pakan dan air minum, sedangkan tikus perlakuan P1 diberi induksi etilen glikol $0.75 \%$ selama 14 hari. Kelompok perlakuan P2 diberi etilen glikol 0.75\% 14 hari kemudian diikuti pemberian ekstrak etanol daun nusa indah putih $150 \mathrm{mg} / \mathrm{kg}$ BB selama 14 hari. Kelompok perlakuan P3 diberi etilen glikol $0.75 \%$ selama 14 hari kemudian diikuti pemberian ekstrak etanol daun nusa indah putih $300 \mathrm{mg} / \mathrm{kgBB}$ selama 14 hari.

\section{Uji Histopatologi ginjal}

Abdomen dibuka kemudian ginjal diambil, dibersihkan dari jaringan sekitarnya kemudian difiksasi dengan larutan Bouin. Selanjutnya di embedding di parafin, dipotong dengan ketebalan $5 \mu$ dan diwarnai dengan hematoksilin-eosin (H-E) (Gambar 2, 3, 4. 5) untuk melihat perubahan histopatologi ginjal 
$[6,7]$.

\section{Analisis Data}

Hasil pengamatan dilihat dari hasil uji skrining fitokimia alkaloid, flavonoid dan saponin. Untuk histopatologi ginjal dianalisis secara deskriptif melihat perubahan histopatologi ginjal melalui mikroskop.

\section{Hasil dan Pembahasan}

\section{Skrining Fitokimia}

Skrining fitokimia merupakan tahap pendahuluan dalam suatu penelitian fitokimia yang bertujuan untuk memberikan gambaran tentang golongan senyawa yang terkandung dalam tanaman yang sedang diteliti [8]. Senyawa-senyawa yang dianalisis meliputi alkaloid, flavonoid dan saponin.

Tabel 1. Hasil skrining fitokimia daun nusa indah putih

\begin{tabular}{cccc}
\hline Bahan & Alkaloid & Flavonoid & Saponin \\
\hline daun & + & + & - \\
nusa & & & \\
indah & & & \\
putih & & \\
\hline Keterangan: $(+)$ Menunjukkan tingkat intensitas warna
\end{tabular}

\section{Alkaloid}

Hasil uji fitokimia alkaloid menunjukkan bahwa sampel daun nusa indah putih positif mengandung alkaloid. Hal ini dibuktikan dengan terbentuknya endapan krem pada tabung reaksi setelah ditetesi pereaksi Meyer. Alkaloid merupakan golongan zat tumbuhan sekunder yang terbesar. Pada umumnya alkaloid mencakup senyawa bersifat basa yang mengandung satu atau lebih atom nitrogen, biasanya dalam gabungan, sebagai bagian dari sistim siklik. Alkaloid seringkali beracun bagi manusia dan banyak yang mempunyai kegiatan fisiologis yang menonjol yang digunakan secara luas dalam bidang pengobatan. Alkaloid biasanya tanpa warna, seringkali bersifat optis aktif, kebanyakan berbentuk kristal tetapi hanya sedikit yang berupa cairan (misalnya nikotina pada suhu kamar) [9].

\section{Flavonoid}

Hasil analisis diketahui bahwa sampel daun nusa indah putih positif mengandung flavonoid ditandai dengan perubahan warna menjadi kuning kehijauan. Flavonoid merupakan istilah yang dikenakan pada suatu golongan besar senyawa yang berasal dari kelompok senyawa yang paling umum yaitu senyawa flavon. Flavonoid mencakup banyak pigmen yang paling umum dan terdapat pada seluruh dunia tumbuhan mulai dari fungus sampai angiospermae [10]. Flavonoid berupa senyawa fenol, karena itu warnanya berubah bila ditambah basa atau anoniak, sehingga flavonoid mudah dideteksi pada kromatogram atau dalam larutan [9].

Secara normal, pembentukan kalsium batu ginjal dihambat oleh flavonoid, kalium, magnesium, dan asam sitrat [11]. Senyawa flavonoid adalah suatu kelompok senyawa fenol yang terbesar ditemukan di alam. Kalsium pada batu ginjal diduga dapat membentuk senyawa kompleks dengan gugus $\mathrm{OH}$ dari flavonoid sehingga membentuk Caflavonoid. Senyawa kompleks ini diduga lebih mudah larut dalam air, sehingga air yang ada dalam urin akan membantu kelarutan batu tersebut. Aktivitas diuretik flavonoid dapat membantu pengeluaran batu dari dalam ginjal yaitu dikeluarkan bersama urin. Dugaan reaksi antara senyawa flavonoid dengan kalsium oksalat dalam batu ginjal ditunjukkan pada Gambar 1. Sementara kalium akan menyingkirkan kalsium dan berikatan dengan oksalat sehingga menjadi senyawa yang lebih mudah larut dalam air [12].

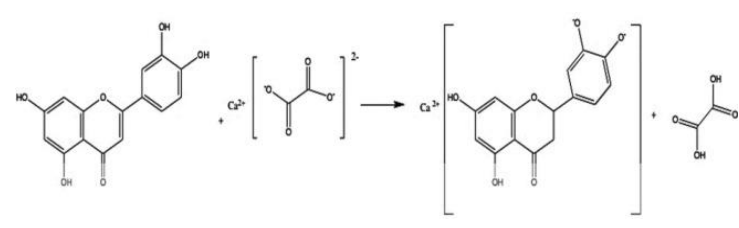

Gambar 1. Dugaan reaksi flavonoid dengan kalsium oksalat [13]

\section{Saponin}

Hasil analisis diketahui bahwa sampel daun nusa indah putih tidak mengandung saponin karena tidak terbentuknya buih/busa setelah pengocokkan. Senyawa yang memiliki gugus polar dan non polar bersifat aktif 
permukaan, sehingga saat saponin dikocok dengan air dapat membentuk misel, gugus polar menghadap ke luar sedangkan gugus nonpolarnya menghadap ke dalam, keadaan inilah yang tampak seperti busa [10].

\section{Histopatologi}

Hasil histopatologi antilitiasis ekstrak etanol daun nusa indah putih menggunakan tikus putih sebagai hewan uji dibagi ke dalam 4 kelompok sebagai berikut:

\section{Hasil Histopatologi Tikus Normal}

Pada kelompok tikus kontrol, gambaran histopatologi menunjukkan korpus renalis dan tubulus ginjal dalam keadaan normal. Sel-sel podosit pada korpus renalis terlihat dalam keadaan normal dengan inti yang terlihat jelas. Ruang kapsular renalis tampak jelas demikian juga dengan kapiler-kapiler yang terdapat pada glomerulus. Pada tubulus terlihat lumen dengan sel-sel dan inti yang utuh dan terlihat dengan jelas (dapat dilihat pada Gambar 2).

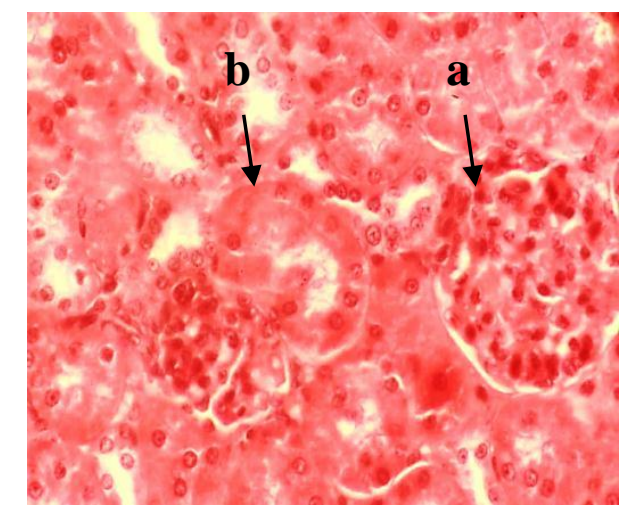

Gambar 2. a. Glomerulus yang ada pada nefron ginjal (tempat penyaringan darah), terlihat dalam keadaan normal tampak jelas.

b. Tubulus yang ada pada nefron ginjal (tempat penyaringan darah) terlihat dalam keadaan normal, tampak jelas dan utuh.

\section{Hasil Histopatologi Tikus yang diberi Etilen Glikol}

Gambaran histopatologi ginjal tikus yang diberikan induksi etilen glikol 0.75\% menunjukkan adanya kerusakan pada korpus renalis dan tubulus ginjal. Sel-sel podosit pada korpus renalis mengalami atropi bahkan kehilangan inti yang ditandai dengan sel-sel yang mulai mengecil dengan warna yang lebih gelap. Hal yang serupa terlihat juga pada kapsula renalis (Bouman) dimana sel-sel epitelium kapsular mengalami atropi (mengecil/mengerut) dan deskuamasi (pengelupasan). Pada tubulus ginjal, sel-sel epitel selain mengalami atropi (mengecil/ mengerut), pignotis (mengecil/menghitam) dan diskuamasi (pengelupasan) juga terlihat adanya infiltrasi sel-sel inflamasi ke dalam lumen tubulus. Hasil penelitian juga menunjukkan pada glomerulus dan tubulus ginjal terdapat endapan mikrokristal dengan terlihat adanya cahaya (dapat dilihat pada Gambar 3).

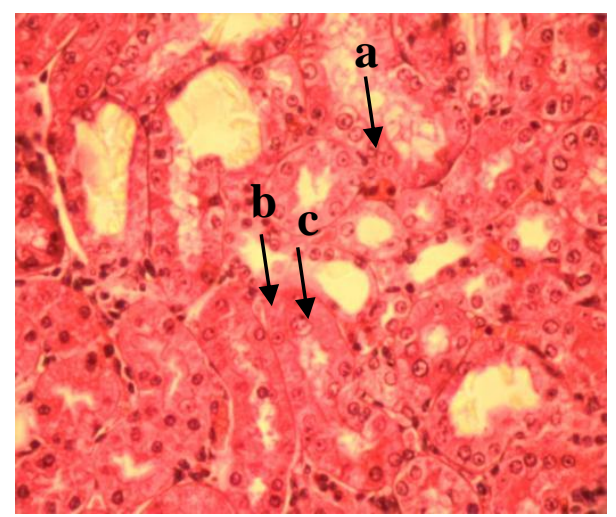

Gambar 3. a. Glomerulus terlihat mengalami deskuamasi (pengelupasan pada glomerulus) dan atropi (mengecil/mengerut) dengan warna lebih gelap.

b. Tubulus terlihat mengalami atropi (mengecil/mengerut), pignotis (mengecil dan warna lebih gelap), diskuamasi (pengelupasan pada tubulus) dan inflamasi (pembengkakan).

c. Mikrokristal atau terbentuknya kristal kecil dengan terlihatnya cahaya pada glomerulus dan tubulus ginjal.

Hasil Histopatologi Tikus yang diberi Ekstrak Etanol Daun Nusa Indah Putih dengan Dosis 150 $m g / k g B B$

Pemberian ekstrak etanol daun nusa indah putih (Mussaenda pubescens) $150 \mathrm{mg} / \mathrm{kg}$ BB pada tikus urolitiasis menunjukkan belum adanya perbaikan yang berarti pada korpus renalis dan tubulus ginjal. Masih terlihat adanya kerusakan pada glomerulus dan tubulus seperti inflamasi, infiltrasi, diskuamasi sel-sel epitel namun tidak terdapat adanya endapan kristal seperti yang terlihat pada ginjal tikus yang diinduksi dengan etilen glikol (dapat dilihat pada Gambar 4). 
Hasil Histopatologi Tikus yang diberi Ekstrak Etanol Daun Nusa Indah Putih dengan Dosis 300 $m g / k g B B$

Pemberian ekstrak etanol daun nusa indah putih (Mussaenda pubescens) $300 \mathrm{mg} / \mathrm{kg}$ BB pada tikus urolitiasis menunjukkan adanya perbaikan pada glomerulus dan tubulus. Dibandingkan dengan dosis $150 \mathrm{mg} / \mathrm{kg}$ BB (Gambar 4), dosis $300 \mathrm{mg} / \mathrm{kg}$ BB menunjukkan adanya perbaikan yang lebih jelas. Tidak terlihat adanya kerusakan pada glomerulus dan tubulus seperti inflamasi (pembengkakan), infiltrasi (kerusakan pada tempat penyaringan darah), diskuamasi (pengelupasan) sel sel epitel dan juga tidak terdapat adanya endapan kristal seperti yang terlihat pada ginjal tikus yang diinduksi dengan etilen glikol (dapat dilihat pada Gambar 5).

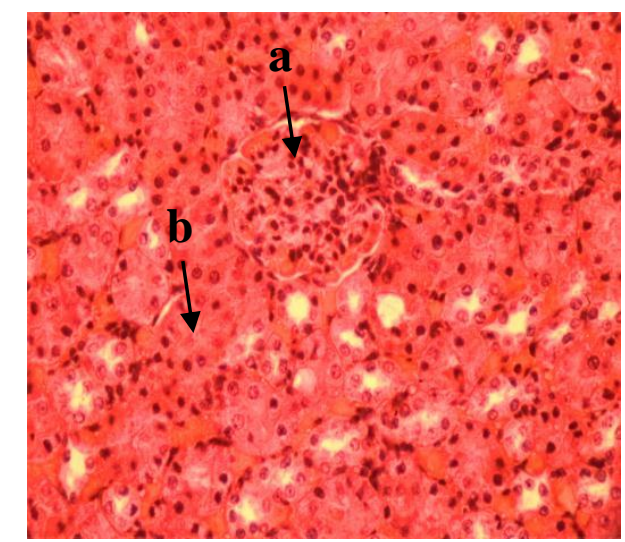

Gambar 4. a. Glomerulus terlihat lebih normal tidak adanya kerusakan pada glomerulus.

b. Tubulus terlihat lebih normal tidak adanya kerusakan pada tubulus.

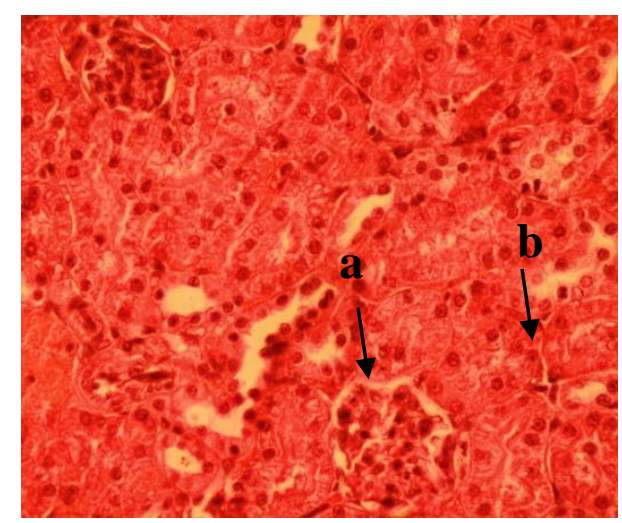

Gambar 5. a. Glomerulus masih terlihat adanya kerusakan seperti inflamasi (pembengkakan) dan diskuamasi (pengelupasan)

b. Tubulus masih terlihat adanya kerusakan seperti inflamasi (pembengkakan), infiltrasi (kerusakan pada tempat penyaringan darah) dan diskuamasi (pengelupasan)

\section{Kesimpulan}

Hasil uji skrining fitokimia daun nusa indah putih (Mussaenda pubescens) positif alkaloid dan flavonoid.

Ekstrak etanol daun nusa indah putih (Mussaenda pubescens) dapat memperbaiki urolitiasis (batu ginjal) dengan dosis $300 \mathrm{mg} / \mathrm{kg}$ BB lebih baik dalam memperbaiki ginjal dibandingkan dengan dosis $150 \mathrm{mg} / \mathrm{kg}$ BB, dilihat dari tidak terlihat adanya kerusakan pada glomerulus dan tubulus seperti inflamasi (pembengkakan), infiltrasi, diskuamasi (pengelupasan) sel-sel epitel dan juga tidak terdapat adanya endapan kristal seperti yang terlihat pada ginjal tikus yang diinduksi dengan etilen glikol.

\section{Daftar Pustaka}

1. Saifudin, A.; Rahayu, V.; Teruna, H. Y., Standarisasi bahan obat alam. Graha Ilmu: Yogyakarta, 2011; Vol. 4, p 69-84.

2. Lee, Y. H.; Huang, W. C.; Huang, J. K.; Chang, L. S., Testosterone enhances whereas estrogen inhibits calcium oxalate stone formation in ethylene glycol treated rats. The Journal of urology 1996, 156, (2), 502-505.

3. Soundararajan, P.; Mahesh, R.; Ramesh, T.; Begum, V. H., Effect of Aerva lanata on calcium oxalate urolithiasis in rats. 2006.

4. Zhao, W.; Wolfender, J.-L.; Hostettmann, K.; Cheng, K.; Xu, R.; Qin, G., Triterpenes and triterpenoid saponins from Mussaenda pubescens. Phytochemistry 1997, 45, (5), 1073-1078.

5. Aloanis, A. A.; Fahriana, F.; Haryadi, H., Skrining fitokimia dan uji toksisitas ekstrak daun balik angin (Mallotus Sp) terhadap larva Artemia salina Leach dengan metode brine shrimp lethality test (BSLT). Fullerene Journal of Chemistry 2017, 2, (2), 77-81.

6. Humason, G. L., Animal tissue techniques. Animal tissue techniques. 1962.

7. Shah, B. N.; Raiyani, K. D.; Modi, D. C., Antiurolithiasis Activity study of Momordica charantia Linn. Fruits. International Journal of Pharmacy Research And Technology 2011, 1, (1), 6-11.

8. Kristanti, A. N.; Aminah, N. S.; Tanjung, M.; Kurniadi, B., Buku ajar fitokimia. 
Surabaya (ID): Airlangga University Pr 2008, 3-161.

9. Harborne, A., Phytochemical methods a guide to modern techniques of plant analysis. springer science \& business media: 1998.

10. Robinson, T.; Padmawinata, K., Kandungan Senyawa Organik Tumbuhan Tinggi, . ITB: Bandung, 1995; p 45-46.

11. Sudoyo, A. W.; Setiyohadi, B.; Alwi, I.; Simadibrata, M.; Setiati, S., Buku ajar ilmu penyakit dalam. Jakarta: Fkui 2006, 400411.

12. Nisma, F., Pengaruh penambahan ekstrak etanol $70 \%$ buah anggur biru (vitis vinifera L.) terhadap kelarutan kalsium batu ginjal. 2011.

13. Taufiq, M. Uji kelarutan batu ginjal dalam ekstrak akuades daun alpukat (Persea americana mill) secara in vitro dan analisis kadar kalsium menggunakan spektrofotometri serapan atom. Universitas Islam Negeri Maulana Malik Ibrahim, 2014. 